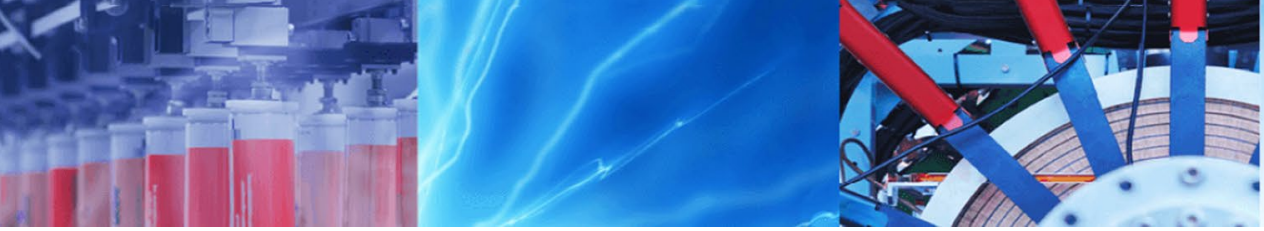

Research Article

\title{
Biogas production as energy source and strategy for managing waste and climate change
}

\author{
Aransıola Elizabeth Funmi ${ }^{1}$ (I) $\cdot$ Momodu Abiodun Suleiman ${ }^{2}$ (D) Okunade Inioluwa Deborah $^{1}$ (I) \\ Adepoju Tofunmi Dorcas ${ }^{1}$ (i)
}

Received: 3 October 2020 / Accepted: 17 December 2020 / Published online: 8 January 2021

(c) The Author(s) 2021 OPEN

\begin{abstract}
The study presents technical and economic approaches of upscaled laboratory experiment using yard waste (YW) and heterogeneous slurry (HS) to produce heat and power, as a means of bridging the gap between energy production and climate change management strategies. A combination of YW:HS in ratio 2:3 with slurry obtained from a functional digester serving as inoculum was fed into the digester. These were mixed in the ratios of substrates/inoculum/water of 3.5:0.173:6.28 and theoretically upscaled for field-scale biodigesters. The modeled result shows that about $2.5 \mathrm{~m}^{3}$ gas is produced per $5-\mathrm{m}^{3}$-sized digester over a 30-day hydraulic retention time and estimated project life of 20 years. A business model was adopted for cost recovery of the proposed waste-to-energy system and life cycle cost analysis for the production costs of the seven $5-\mathrm{m}^{3}$ digesters. Avoided emissions of $\mathrm{CO}_{2}$ from other equivalent energy sources are $4.36 \mathrm{~kg}, 10.16 \mathrm{~kg}, 10.37 \mathrm{~kg}$, and $81.32 \mathrm{~kg}$, respectively, for LPG, kerosene, diesel and fuel wood/charcoal. The project is sustainable in for profit, people and planet.
\end{abstract}

Keywords Biogas · Waste-to-energy $\cdot$ Climate change management $\cdot$ Energy source $\cdot$ Waste $\cdot$ Strategy

\section{Introduction}

Degradable wastes do contribute to release of greenhouse gases (GHG), particularly methane, to the atmosphere [1]. This could have negative climate change effect through the release of greenhouse gases to the atmosphere. However, proper management of these wastes, particularly through energy recovery and recycling amongst others [2], could mitigate this effect. Global waste generation is estimated at 0.26 tons per capita, and it is projected to increase by $70 \%$ in 2050 [3]. Per capita waste production in sub-Saharan Africa has an average of $0.65 \mathrm{~kg}$ per person per day [4]; in Nigeria, it is $0.43 \mathrm{~kg} / \mathrm{head}$ per day and $60-80 \%$ of it is organic $[5,6]$. Organic wastes produced within human settlements include food waste (FW), agricultural waste, yard waste (YW), human and animal waste $[7,8]$. Studies show that wastes, particularly organic wastes, are improperly managed in Nigeria [7], [8], inducing the necessity to find and implement suitable methods of waste management, such as the use of anaerobic digestion. Anaerobic digestion (AD) is a nonthermal technological approach to waste management.

The use of $A D$ as a waste management technology has huge potential to meet both purposes of mitigation and adaptation approaches in climate change management strategies [9]. AD produces biogas that can be used as a substitute in various sectors, including transportation, agriculture, residential/household and industrial sectors. The gas can be particularly helpful in cottage industries in the rural areas for processing of agricultural products

\footnotetext{
$\triangle$ Momodu Abiodun Suleiman, abiodunmomodu8@gmail.com; Aransıola Elizabeth Funmi, aransiolaef@gmail.com; Okunade Inioluwa Deborah, okunadeinioluwa@yahoo.com; Adepoju Tofunmi Dorcas, adepojutofunmi001@gmail.com|'Department of Chemical Engineeering, Obafemi Awolowo University, Ile-Ife, Nigeria. ${ }^{2}$ Centre for Energy Research and Development, Obafemi Awolowo University, lle-Ife PMB 024, Nigeria.
} 
such as provided needed energy for frying of milled cassava to garri. For example, the use of biogas produced from $A D$ technology has been shown to reduce the use of fuel wood and this in turn lessens forest degradation [10] (energy need for garri processing is discussed in more detail in a later section). Also, AD of vegetal organic waste could reduce particulate matter by $5.3 \%$, climate change by $6.4 \%$ and ozone depletion by $13.4 \%$ as opposed to using them directly as fertilizers in farms [11]. These facts highlight the need to develop integrated AD systems that not only mitigate the GHG emission from by-products of agriculture but will also serve as energy source which can then be put into agricultural processing. However, implementing the production of biogas for energy production in Nigeria is faced with a number of challenges, insufficient amounts of substrate for biogas generation [12] and unavailability of local technology in developing countries leading to increased cost of putting biogas to use [13]. Despite these, however, biogas production can still play a vital role in augmenting communal energy needs particularly in rural settings, hence this study.

Broadly, the study evaluates the means of using an upscaled-sized digester for biogas production in energy utilization as a climate change mitigation strategy. A business model was developed for scaling up laboratory experiment to a field-scale level. Specific objectives are to: design series of stainless steel digesters to the capacity of $35 \mathrm{~m}^{3}$; scale up experimental data on yard waste, heterogeneous slurry and inoculum as seed from a functioning digester to generate biogas as an alternative fuel to existing fossil fuel resources [14], formulate a business model of life cycle costs and revenue stream; and estimate avoided emissions for other fuel types used for cooking or electricity generation.

\section{Theoretical development}

\subsection{Biodigesters and biogas production}

There are several types of commercially utilized digesters. These include the fixed dome, plug flow and bag types [15-17]. The type used for this study is the plug flow fixed dome digester chosen because of ease of construction and the relatively low cost of materials. For the experimental study, the feedstock used for the substrates is food waste (FW) because of its relatively high degradability, nutrient content and methane yield $[18,19]$, and $Y W$ to balance the $\mathrm{C} / \mathrm{N}$ ratio of FW [20]. However, because of other competing uses to which FW is put to, the scaling up process only considered the use of YW mixed with heterogeneous manure involving swine manure, poultry litters and droppings. Co-digesting $\mathrm{YW}$ with this heterogeneous manure leads to higher biomethane potential (BMP) yields [21]. Co-digestion is usually influenced by $\mathrm{C} / \mathrm{N}$ ratio, and it has been shown that the optimal ratio is 25-30:1 [22], [23].

Biogas is produced when organic matter is anaerobically broken down. It is largely composed of methane $\left(\mathrm{CH}_{4}\right)$ and carbon dioxide $\left(\mathrm{CO}_{2}\right)$ with small amounts of water and other gases. The composition of the biogas depends on the substrate and the conditions of digestion [24]. Biogas is produced in four stages: hydrolysis, acidogenesis, acetogenesis and methanation [25], with its production being influenced by several factors including temperature, $\mathrm{pH}$ and inoculation [26]. Estimating the performance of substrates in a biodigestion process involves carrying out a number of preliminary tests on the substrate including biomethane potential (BMP) [27], total solids (TS) and volatile solids (VS) [28], carbon-nitrogen (C/N) ratio [29] and nutrient content analysis [19].

\subsection{Energy need for garri processing}

Garri is an important staple food made from grated cassava (Manihot esculenta) in Nigeria and probably all the countries in West Africa. It is usually processed by women through peeling, washing, grinding, fermenting and roasting of the milled cassava (see Fig. 1. This analysis focuses on roasting milled cassava to garri. Between 22.6 and $33.8 \mathrm{~kJ}$, or an average of approximately $28.2 \mathrm{~kJ}$ of thermal energy is needed for the production of garri from $1 \mathrm{~kg}$ of milled cassava (Jekayinfa [30, 31].

\section{Methodology}

The laboratory-scale study focused on the use of food wastes (FWs) and yard wastes (YWs) as substrate. The FW used is mainly leftovers of cooked rice in all forms, while YW is taken to include but not limited to, leaves, wood chips and twigs. These were mixed with heterogeneous manure from swine and poultry sources, used as substrates in the digester. The mixture ensured a carbon-nitrogen $(\mathrm{C} / \mathrm{N})$ ratio for effective production of methane and to also dilute inhibitors and toxic compounds [20]. Through the laboratory-scale experiment, basic data needed to design field-scale digesters were generated. Field-scale digesters are needed to handle municipal solid wastes (MSWs) of any kind to generate biogas. The steps taken included constructing laboratory-scale biodigesters, collecting and preparing required wastes to be fed into the biodigesters, batch feeding of the biodigesters, taking of daily readings of biogas yield and temperature per digester, and conducting laboratory tests on the substrates. Scaling up the laboratory-scale to field-scale production involves business model formation Fig. 2. 
Fig. 1 Semi-mechanized garri processing plant-[32]

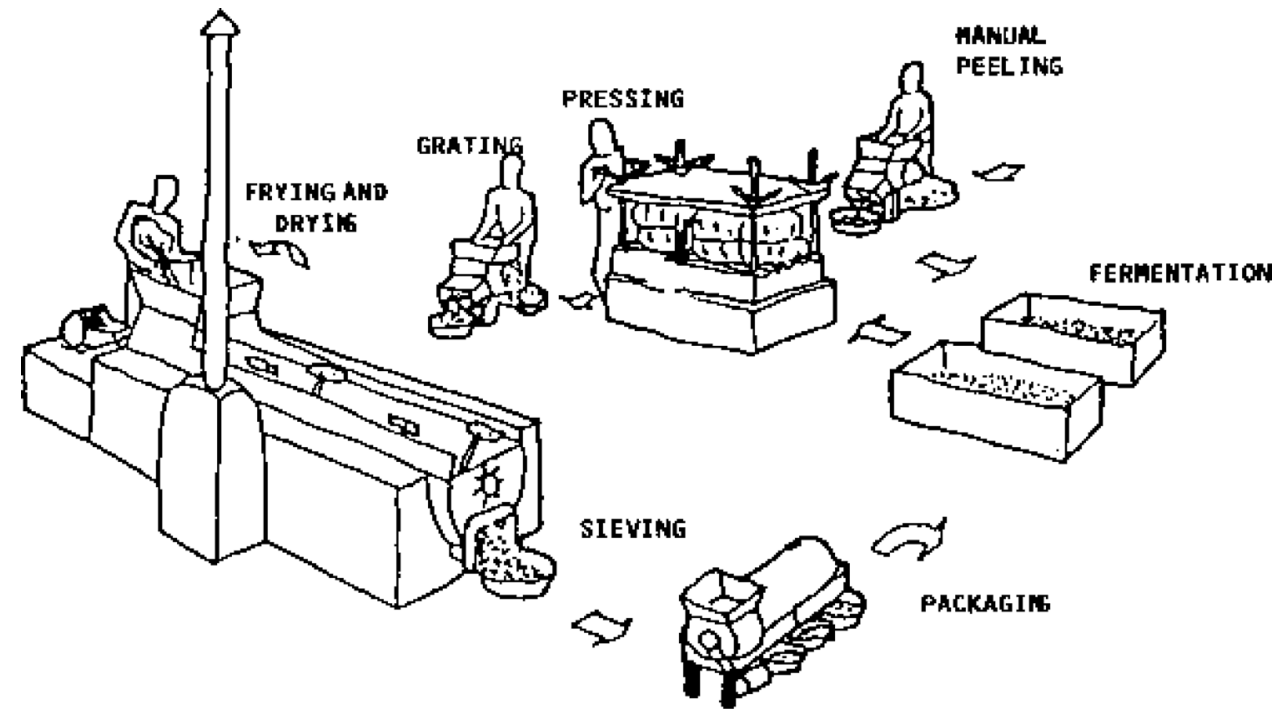

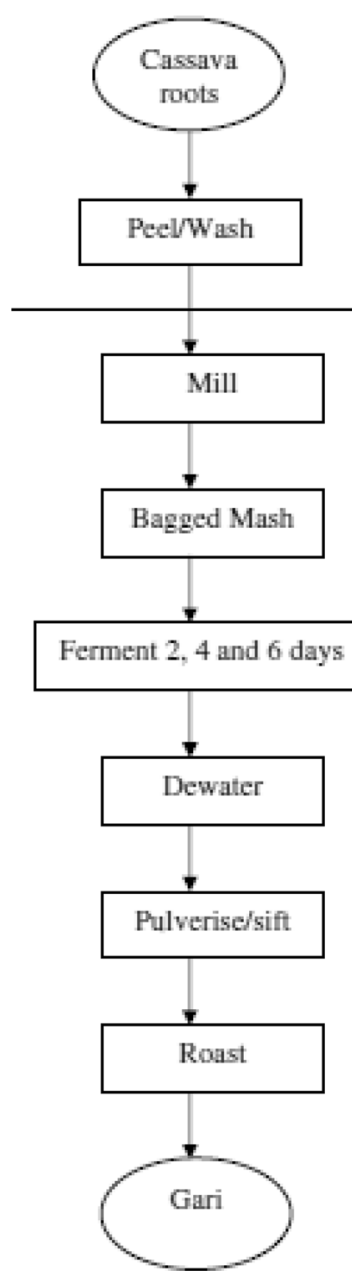

Fig. 2 Processing steps for garri, a cassava-based product-[30]

\subsection{Business model formulation}

Scaling up biogas production from the laboratory-scale to field-scale level requires implementing a business model. A business model describes the rationale of how an organization creates, delivers and captures value in economic, social, cultural or other contexts while business model innovation is the process of formation of a business model [33], [34]; it encompasses a wide range of factors [35]. There are two broad types of business models: traditionally funded business models that are typically government-owned and private market-driven business models. The private market-driven models are further subdivided into one-hand business model, two-hand business model, fee-for-service or pay-as-you-go (PAYG) business model and lease/hire purchase business model [36]. Further classification of business models can be found in [37] and [38]. Most businesses usually operate by making use of any combination of these models.

\subsection{Materials and methods}

The feedstock is made up of a mixture of food wastes (FWs), which was collected from various restaurants and food production outlets, and yard wastes (YWs), collected from various sources such as small-scale farms, and the lawn mowing, hedge and tree trimmings. The slurry was collected from an operational heterogeneous digester for inoculum.

The co-substrates were combined by targeting the standard carbon-nitrogen ratio $(\mathrm{C} / \mathrm{N})$ which is $25: 1$, the $\mathrm{C} / \mathrm{N}$ of yard waste is $30: 1$ while that of food waste is $20: 1$ [39]. The calculation of the co-substrate $\mathrm{C} / \mathrm{N}$ is shown below: 
Yard waste $(Y W)=\frac{30}{50} \times 25=15:$

Foodwaste $(F W)=\frac{20}{50} \times 25=10$

YW:FW ratio in order to balance the carbon-nitrogen ratio is $15: 10$ which is $3: 2$.

The co-substrates were combined in a mass ratio of 3:2 that is $\mathrm{YW}$ to $\mathrm{FW}$ in order to balance the $\mathrm{C} / \mathrm{N}$ ratios [20]. The ensuing mixture was then combined in the ratio of co-substrates/inoculum/water of 3.5:0:8 for the control digester, namely D1,3.5:1.15:6.85 for the digester with 10\% inoculation referred to as D2, and 3.5:0.173:6.28 for the digester with $15 \%$ inoculation referred to as D3. The digesters were fed with these substrate mixtures accordingly and sealed. Samples of the YW, FW and inoculum were used to determine VS, TS and BMP for characterization of the substrate.

The TS was determined by heating a pre-weighed sample to a constant weight at $105^{\circ} \mathrm{C}$ and calculated using

$\mathrm{TS}=\frac{M_{\mathrm{a}}}{M_{\mathrm{b}}} \times 100$

where $M_{\mathrm{a}}$ and $M_{\mathrm{b}}$ represent the final and initial masses, respectively

The VS was then determined using the same sample mass by heating at $550{ }^{\circ} \mathrm{C}$ till; again, a consistent mass is reached and then the VS content is determined using Eq (2):

$\mathrm{VS}=\frac{M_{\mathrm{c}}}{M_{\mathrm{d}}} \times 100$

where $M_{\mathrm{c}}$ and $M_{\mathrm{d}}$ represent the final and initial masses, respectively.

The BMP was determined by first obtaining the Infrared (IR) spectra of the samples using a Shimadzu FTIR 8400 S Fourier transform infrared (FTIR) spectrophotometer and then followed by calculation of the BMP using the partial least squares model as described in [40], [41]. The temperature and volume of gas produced by each digester were measured each day. Data obtained were used to determine the optimal conditions for anaerobic digestion of the mixture of food and yard wastes.

These laboratory-scale results were then adapted for upscaling of the biodigester size and the substrates to be used through business model formation. The template used for this study is a private market- driven business model, particularly for the sales of biogas to enable cost recovery. The private market-driven business model will cater to lack of technology and technical competence in the target areas, customers' commitment to long-term use of the product or customers being able to pay for the
Table 1 Result of TS and VS tests

\begin{tabular}{llcl}
\hline & TS & VS & VS/TS \\
\hline Inoculum & 2.462063 & 1.740963 & 0.707116 \\
YW & 83.03881 & 25.31098 & 0.304809 \\
FW & 36.60695 & 29.02401 & 0.792855 \\
Digester 1 & 22.44509 & 9.22089 & 0.41082 \\
Digester 2 & 26.21811 & 4.82491 & 0.184030 \\
Digester 3 & 10.9981 & 1.29040 & 0.117329 \\
\hline
\end{tabular}

Table 2 Calculated BMP values

\begin{tabular}{ll}
\hline Digester & $\begin{array}{l}\mathrm{BMP}\left(\mathrm{ml} \mathrm{CH}_{4}\right. \\
\text { per gram VS) }\end{array}$ \\
\hline YW & 1396.78 \\
FW & 424.1549 \\
\hline
\end{tabular}

product in affordable increments also known as pay-asyou-go, as opposed to paying a one-time upfront investment [42].

In the business model, biogas is an energy product intended to bridge a gap in terms of cooking needs and electricity supply. The market for biogas in rural areas is quite huge, but it is yet to be accepted as an energy source in Nigeria, whereas in Norway, Germany, India and parts of China, for example, the use of biogas is common place as compared to Nigeria, where biogas utilization is near zero. To mitigate business risks, communities in target areas will be made shareholders or asked to provide equity.

\section{Results and discussions}

The results of the laboratory-scale experiments including tests/analysis conducted and readings that were taken are presented. The tests/analysis conducted is for the TS, VS and FTIR to determine BMP, and the readings taken are for daily temperature and gas yield, respectively. The result of the TS and VS tests is shown in Table 1. The table shows the characterization of the inoculum and the FW having high solid content at over $70 \%$ each, while that for the $\mathrm{YW}$ is low at about $30 \%$. This characterizes the process as solidstate anaerobic digestion (SS-AD) [43]. SS-AD has multiple advantages including high organic loading, minimal digestate generated and low energy requirement for heating. In contrast, SS-AD has long solid retention time, incomplete mixing and an accumulation of inhibitors [44]. The mixture in the digesters showed a lower rate of volatile solids after they were diluted with water.

In the laboratory experiment, the measured values of TS and VS differed from what was expected. This could be adduced to the disadvantage of incomplete mixing in the 
SS-AD constituents which were not homogenous when withdrawn for sampling. However, the calculation Table 2 of TS and VS values of $\mathrm{H}, \mathrm{FW}$ and $\mathrm{YW}$ showed consistency with what obtains in the literature as (see [20], [45]). The VS/TS ratios of the digester substrates lie between those for YW and FW because the substrates are a mixture of the YW and FW. digester 1 had the highest VS/TS ratio followed by digesters 2 and 3 , respectively. This implies that digester 1 has the predisposition to produce the highest amount of gas followed by digesters 2 and 3, respectively.

The IR spectra of the samples acquired using Shimadzu FTIR 8400 S spectrophotometer are shown in Figs. 3 and 4. The combined spectra, obtained using MATLAB, are shown in Fig. 3. The spectra were then used to obtain the functional groups and BMP of the substrates.

The functional groups in the YW sample were determined using the peaks in zones 1-5 of the acquired
IR spectra for the YW. The peak $3417.98 \mathrm{~cm}^{-1}$ indicates the presence of alcohol, $2920.32 \mathrm{~cm}^{-1}$, aldehyde, $2850.88 \mathrm{~cm}^{-1}$, alkyl, $2166.13 \mathrm{~cm}^{-1}$ and $2054.36 \mathrm{~cm}^{-1}$, alkynes, $1722.49 \mathrm{~cm}^{-1}$, aldehyde, $1620.26 \mathrm{~cm}^{-1}$, alkyne, and $1514.17 \mathrm{~cm}^{-1}$, benzene ring. For the $\mathrm{FW}$, the peaks in zones $1-5$ of the acquired IR spectra were also used to identify the functional groups. The peaks $3558.48 \mathrm{~cm}^{-1}$ and $3414.12 \mathrm{~cm}^{-1}$ are indicative of the presence of amines, $3010.98 \mathrm{~cm}^{-1}$ and $2926.11 \mathrm{~cm}^{-1}$, aryl groups, $2854.74 \mathrm{~cm}^{-1}$, alkyl group, $2168.06 \mathrm{~cm}^{-1}$ and $2052.33 \mathrm{~cm}^{-1}$, Alkyne, $1745.64 \mathrm{~cm}^{-1}$, aldehyde, $1639.55 \mathrm{~cm}^{-1}$ and $1550.82 \mathrm{~cm}^{-1}$, benzene ring, and $1465.95 \mathrm{~cm}^{-1}$ alkane group. The combined spectra Fig. 5 present a combined peak for FW and YW as has been described.

The daily gas yields for each digester are shown in Figs. 6, 7 and 8. The gas yields were measured in liters using water displacement.

Fig. 3 IR spectra of YW

Ф SHIMADZU

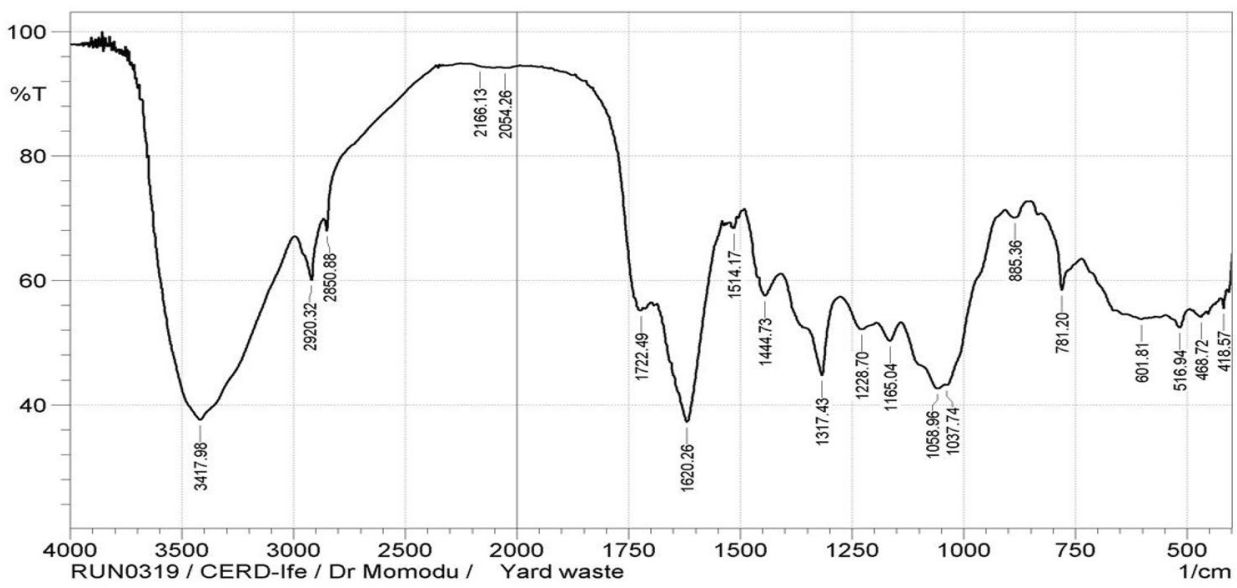

Fig. 4 IR spectra for FW

ФSHIMADZU

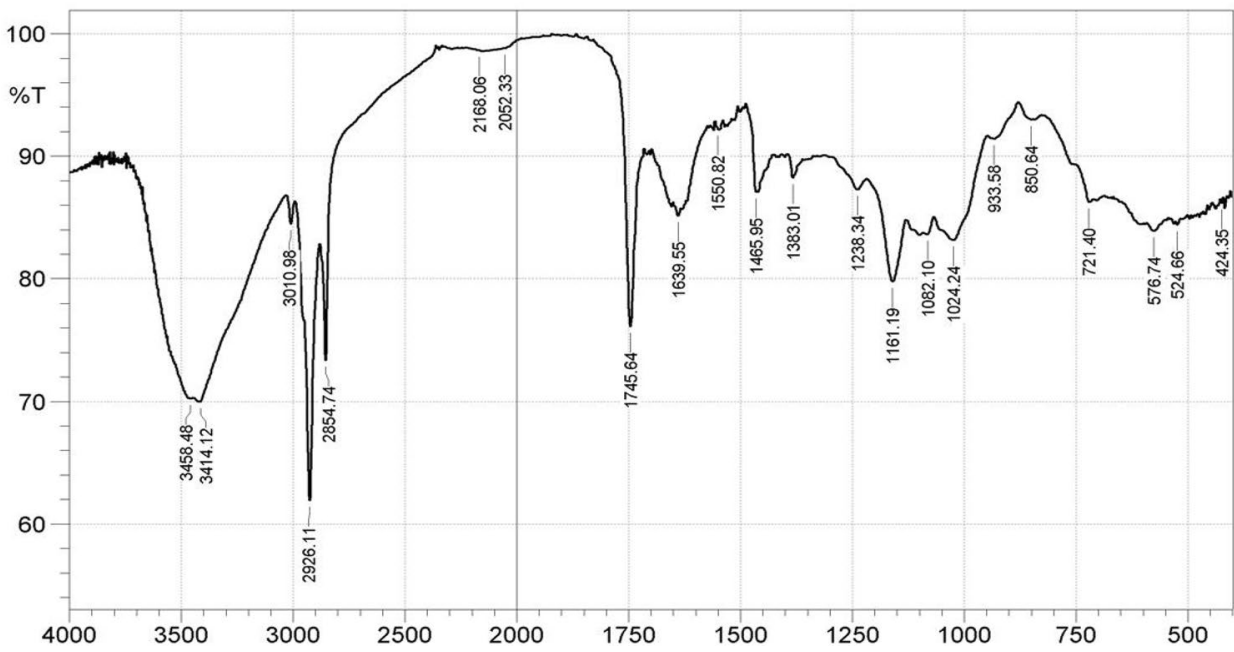

SN Applied Sciences 


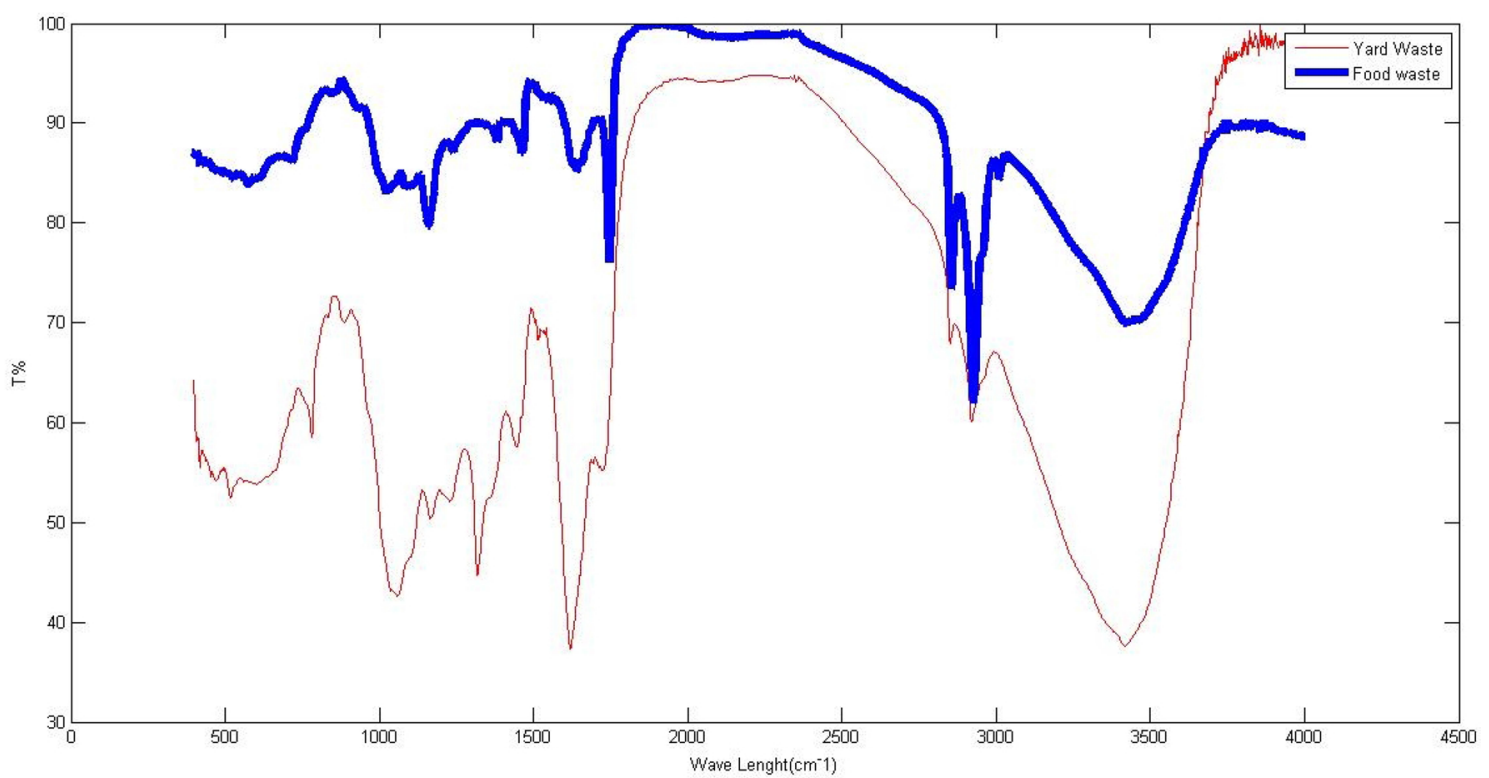

Fig. 5 Combined IR spectra

D1 Volume (L)

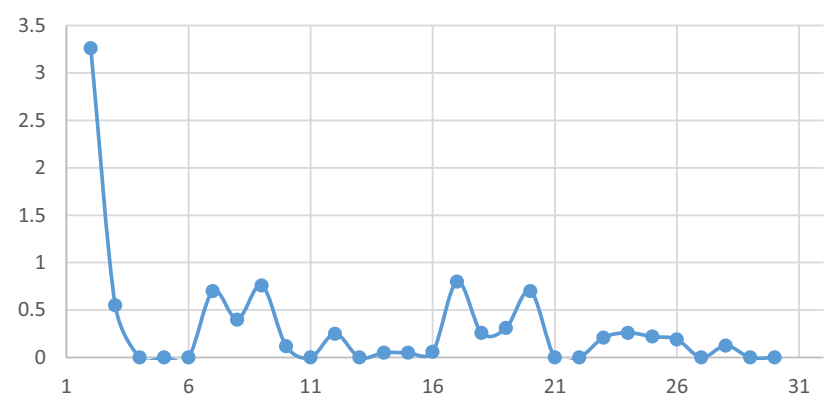

Fig. 6 Graph of gas produced daily by digester 1

\section{D2(volume (L))}

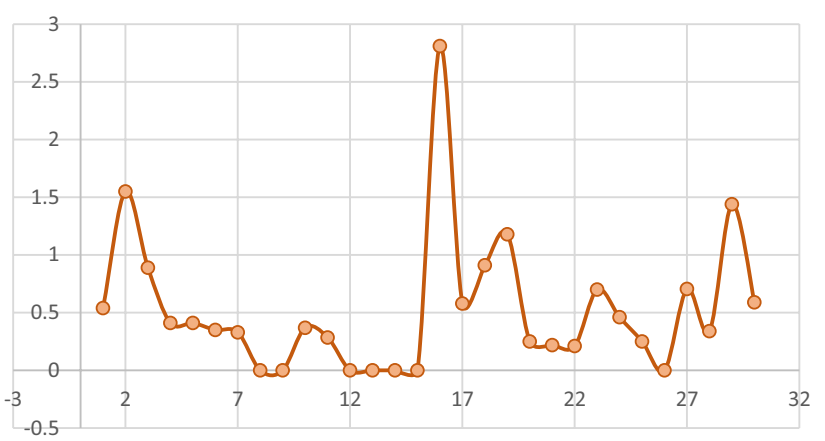

Fig. 7 Graph of gas produced daily by digester 2

The volume produced per day per digester in the laboratory-scale experiment was analyzed using one-way
D3 Volume Produced (L)

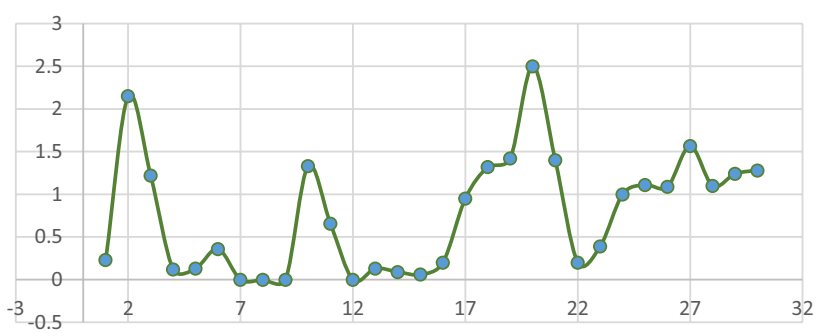

Fig. 8 Graph of gas produced daily by digester 3

Graph of temperature and Volume for Digester 1

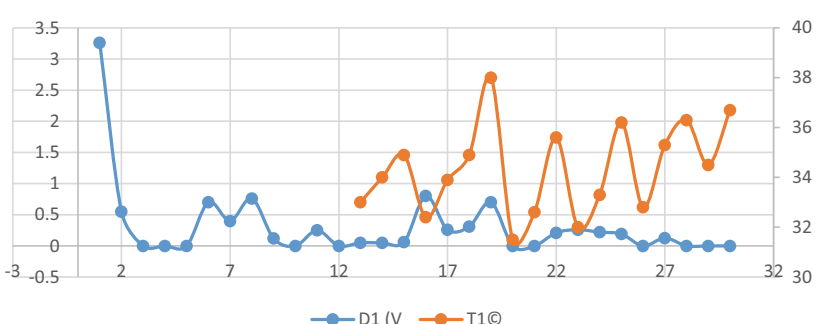

Fig. 9 Graph of temperature and volume for digester 1

ANOVA with $a=0.05$. The ANOVA test showed that the inoculum has a significant effect on the volume of gas produced. The data were further subjected to $t$ test with two samples and the assumption of equal variance at the same value of $a$, and the analysis showed that although 


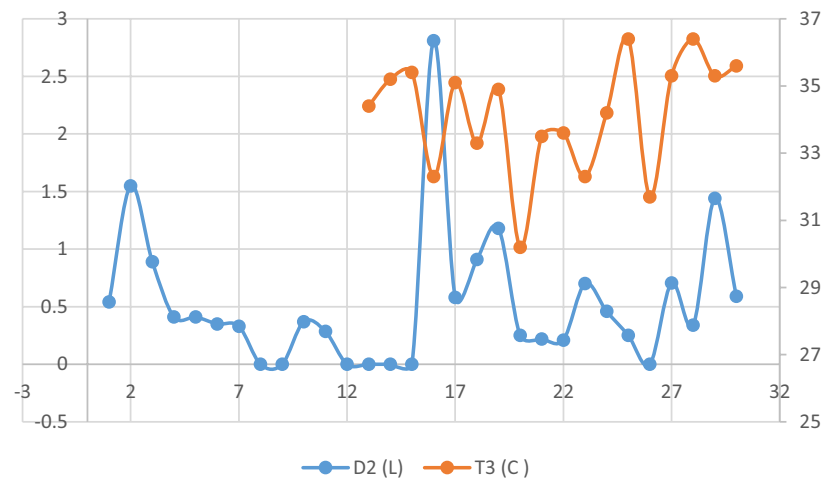

Fig. 10 Graph of temperature and volume for digester 2

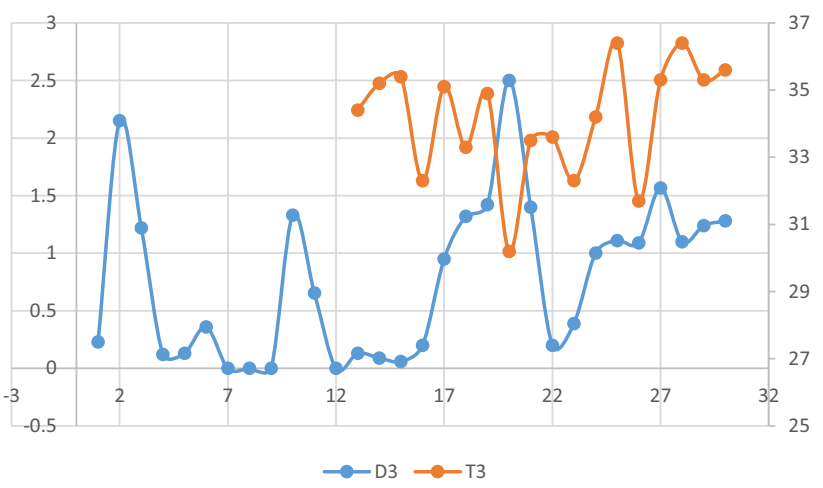

Fig. 11 Graph of temperature and volume for digester 3

the influence of addition of inoculum was significant, there was no statistically noticeable difference between the volumes produced by digesters 2 and 3 and hence the $10 \%$ and $15 \%$ inoculum addition.
The relationship between volume of gas produced and digester temperatures is shown in Figs. 9, 10 and 11 .

Estimated energy from the expected quantity of biogas to be produced from the biodigesters is used to calculate the quantity of milled cassava that would be processed into garri using the postulated biogas setup. Theoretically, the digesters are estimated to produce about $213.5 \mathrm{~kg}$ of biogas with equivalent energy of $332.5 \mathrm{MJ}$ within a 30-day period or an average of $7.11 \mathrm{~kg}$ per day. From the earlier assessment, the average energy needed to produce garri from $1 \mathrm{~kg}$ of milled cassava is put at $22.8 \mathrm{~kJ}$. Therefore, the average amount of biogas produced per day will theoretically be enough to process about $400 \mathrm{~kg}$ of milled cassava into garri with efficiency of the biogas burning assumed at $100 \%$.

The business is expected to operate by getting substrate from the community, and revenue from selling the gas generated, and the technology, which is the basis for the business model formulation. The preferred method of payment follows the pay-as-you-go (PAYG) model, and the reasons for this have been highlighted in the preceding section.

The cost estimate used in this study is an approximate method which is based on limited cost and design information just to show that the project is economically feasible. The gas produced is assumed to be used for two things: heating and electricity generation using gas burners for cooking and an internal combustion (IC) engine for electricity generation. The IC was chosen because it is the most used for landfill electricity generation and is cheaper to operate than both gas turbine systems and steam turbine systems [46].

This design is based on seven different $5-\mathrm{m}^{3}$ digesters to give a total of $35 \mathrm{~m}^{3}$; these are projected to service 100

\begin{tabular}{lrcc}
\hline Item & Estimated cost & $\begin{array}{l}\text { Estimated } \\
\text { quantity }\end{array}$ & Cost \\
\hline Digester tanks $75 \mathrm{~m}^{3}$ tanks & $\$ 1111.11$ & 7 & $\$ 7777.78$ \\
Storage tanks & $\$ 555.56$ & 14 & $\$ 7777.78$ \\
Different sizes of PVC pipes & $\$ 1.39$ & 25 & $\$ 34.72$ \\
Different sizes of connecting tubes & $\$ 0.69$ & 60 & $\$ 41.67$ \\
Valves & $\$ 2.78$ & 25 & $\$ 69.44$ \\
Site construction & $\$ 277.78$ & 1 & $\$ 277.78$ \\
Transportation & $\$ 138.89$ & 1 & $\$ 138.89$ \\
Labor costs & $\$ 27.78$ & 25 & $\$ 694.44$ \\
Construction of 3-burner gas stoves & $\$ 16.67$ & 50 & $\$ 833.33$ \\
Communication & $\$ 55.56$ & 1 & $\$ 55.56$ \\
Substrate collection first time & $\$ 1138.89$ & 0 & - \\
R\&D & $\$ 2777.78$ & 1 & $\$ 2777.78$ \\
Vaporizer for generator & $\$ 2777.78$ & 1 & $\$ 2777.78$ \\
Sum & & & $\$ 23256.94$ \\
\hline
\end{tabular}


Table 4 Operation and maintenance costs

\begin{tabular}{lllr}
\hline ITEM & Estimated cost & $\begin{array}{l}\text { Estimated } \\
\text { quantity }\end{array}$ & Cost \\
\hline O\&M & $\$ 2777.78$ & 1 & $\$ 2777.78$ \\
$\begin{array}{l}\text { Iron filling and } \\
\text { steel wool }\end{array}$ & $\$ 69.44$ & 350 & $\$ 24305.56$ \\
\hline
\end{tabular}

Table 5 Energy content of various fuels on a basis of $21.35 \mathrm{~kg}$ of methane generated per day

\begin{tabular}{lcc}
\hline & Mass $(\mathrm{kg})$ & $\begin{array}{l}\text { Energy } \\
\text { content } \\
(\mathrm{MJ})\end{array}$ \\
\hline Biogas & 21.35 & 332.5 \\
LPG & 7.875 & 26565.7 \\
Kerosene & 10.5 & 29347.8 \\
Fuel wood & 61.25 & 66195.7 \\
Petrol & 12.25 & 41086.9 \\
Diesel & 8.75 & 28695.7 \\
\hline
\end{tabular}

rural households. The total capital cost of the system is estimated as shown in Table 3. It is anticipated that revenue would be generated via selling the digestate to farmers as organic fertilizer and the electricity to the local consumer. The price of the digestate was pegged at about $\$ 5.6$ per Mg while that of the electricity was pegged at $\$ 0.0027$ per kBTU. These prices were chosen with respect to the prevailing market prices in SW Nigeria as at when this study was conducted.

For the recurring costs, the YW and HS will be sourced from local farmers. Since yard waste was hitherto a waste product in these communities, the authors felt the price of $\$ 0.06$ per kilogram was justified. The iron and steel filings for the gas pipes are estimated to cost $\$ 69.44$ per month for 350 months, and the general operation and maintenance cost on a yearly basis are estimated to be about $\$ 2800$ shown in Table 4.

The expected emissions were estimated, and their values are compared with those from conventional fuel sources on the basis of energy generated. The results are shown in Tables 5, 6 and 7.
Table 7 Avoided emissions when biogas is compared with other fuel sources

\begin{tabular}{llll}
\hline & $\begin{array}{l}\text { Avoided emis- } \\
\text { sion } \mathrm{CO}_{2}(\mathrm{~kg})\end{array}$ & $\begin{array}{l}\text { Avoided emis- } \\
\text { sion } \mathrm{CH}_{4}(\mathrm{~kg})\end{array}$ & $\begin{array}{l}\text { Avoided } \\
\text { emission } \mathrm{NO}_{2} \\
(\mathrm{~kg})\end{array}$ \\
\hline Biogas & 0 & 0 & $0.00 \mathrm{E}+00$ \\
LPG & 4.33576 & $2.39225 \mathrm{E}-05$ & $2.39 \mathrm{E}-06$ \\
Kerosene & 10.15613 & 0.00084875 & $2.03 \mathrm{E}-04$ \\
Fuel wood & 81.3155 & 0.02631125 & $3.55 \mathrm{E}-02$ \\
Diesel & 10.374 & 0.0008225 & $1.51 \mathrm{E}-03$ \\
\hline
\end{tabular}

As seen from Table 7, since all the values of avoided emissions from comparative fuels show positive values, it follows that switching from these conventional fuel sources to biogas for meeting rural energy needs will be of immense benefit to humans as well as the environment at large due to the health effects and greenhouse effect of these gases.

The economic evaluation of the feasibility for upscaling this project was carried out via the life cycle cost of the project using three different scenarios. In scenario A, it was assumed that all the generated biogas would be channeled into cooking and the digestate would be sold to local farmers; in scenario $B$ it was assumed that all the gas would be used for electricity generation while also selling the digestate to be used as biofertilizer; scenario $C$ would involve the middle ground scenario by splitting the produced gas between cooking and electricity generation half-in-half. The sales price was calculated by adding $40 \%$ to the LCC split into $25 \%$ bank interest, $5 \%$ profit $5 \%$ VAT and $5 \%$ sales tax. From these prices and the quantity of gas and digestate expected, the revenue for the three scenarios was determined. The values calculated for each of the scenario are shown in Table 8.

The business model was developed by considering the peculiarities of the communities where the biogas plants are intended to be implemented and the available resources. The communities are agrarian in nature and have a relatively high number of unemployed people indicating that there is a ready workforce and a significant amount of material to be used as substrate. The business model is shown in Fig. 12. The revenue sources are sales of
Table 6 Amount of gasses emitted and avoided emissions when biogas is compared with other fuel sources

\begin{tabular}{lllllll}
\hline & $\begin{array}{l}\text { Emission fac- } \\
\text { tor }(\mathrm{CO} 2)\end{array}$ & $\mathrm{EF} \cdot \mathrm{CH}_{4}$ & $\mathrm{EF} \cdot \mathrm{NO}_{2}$ & $\begin{array}{l}\text { Amount emit- } \\
\text { ted } \mathrm{CO}_{2}(\mathrm{~kg})\end{array}$ & $\mathrm{AE} \cdot \mathrm{CH}_{4}(\mathrm{~kg})$ & $\mathrm{AE} \cdot \mathrm{NO}_{2}(\mathrm{~kg})$ \\
\hline Biogas & 0.0546 & 0.000001 & $1.00 \mathrm{E}-07$ & 18.1545 & 0.0003325 & $3.33 \mathrm{E}-05$ \\
LPG & 0.0631 & 0.000001 & $1.00 \mathrm{E}-07$ & 22.49025975 & 0.000356423 & $3.56 \mathrm{E}-05$ \\
Kerosene & 0.0719 & 0.000003 & $6.00 \mathrm{E}-07$ & 28.310625 & 0.00118125 & $2.36 \mathrm{E}-04$ \\
Fuel wood & 0.112 & 0.00003 & $4.00 \mathrm{E}-05$ & 99.47 & 0.02664375 & $3.55 \mathrm{E}-02$ \\
Diesel & 0.0741 & 0.000003 & 0.000004 & 28.5285 & 0.001155 & $1.54 \mathrm{E}-03$ \\
\hline
\end{tabular}


Table 8 Revenues for scenarios A, B and C

\begin{tabular}{lcrllll}
\hline & LCC & Sale price & Quantity & $\begin{array}{l}\text { Revenue } \\
\text { scenario A }\end{array}$ & $\begin{array}{l}\text { Revenue } \\
\text { scenario B }\end{array}$ & $\begin{array}{l}\text { Revenue } \\
\text { scenario C }\end{array}$ \\
\hline Cooking & 153.423 & 214.792 & 128100 & $\$ 76430.28$ & - & $\$ 50953.52$ \\
Electricity & 0.009 & 0.012 & 2280444600 & - & $\$ 76430.28$ & $\$ 50953.52$ \\
Digestate & 134.97 & 188.956 & 145615.461 & $\$ 76430.28$ & $\$ 76430.28$ & $\$ 50953.52$ \\
\hline
\end{tabular}

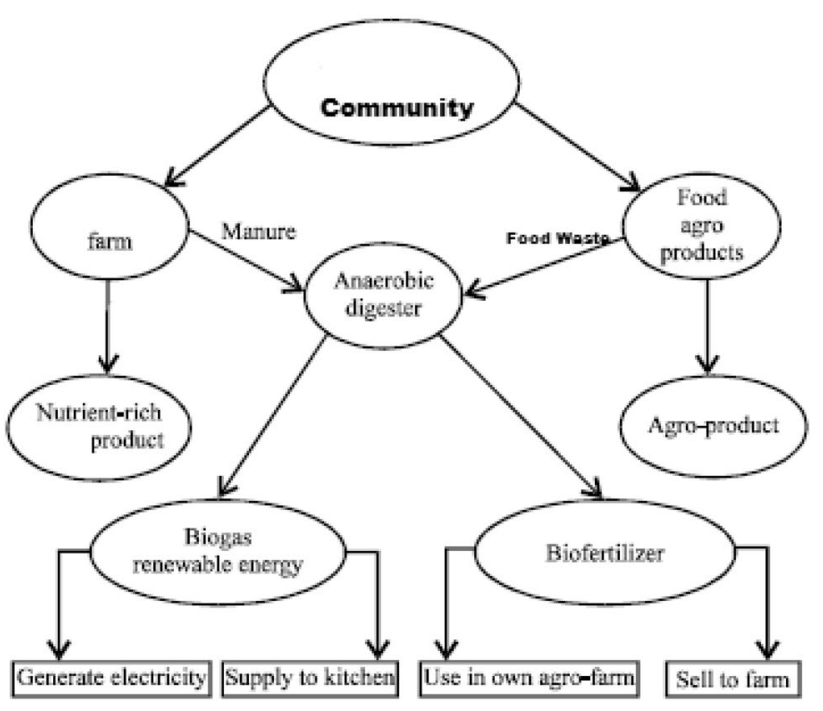

Fig. 12 Business model

generated biogas, and generated electricity-should the community choose to generate electricity-and of biofertilizers while the expected expenses are for purchase of waste, employing manpower and maintenance of biodigester facilities.

The cost and emission analysis show that scaling up the laboratory experiment, using a hypothetical community of 300 households, is both economically feasible and environmentally advantageous. In similar vein, if the postulated biogas is used for garri processing from milled cassava, it is able to service the production of about 0.4 tons of grated cassava per day. The venture would be a profitable and replicable one so long as the environmental conditions are similar and with readily available and cheaply acquired feedstock.

\section{Conclusion}

Good management of degradable wastes using SS-AD, an example of which is discussed in this study, is one important strategy that could be adapted for mitigating the effect of greenhouse gas emissions to the atmosphere (see [43]). This can also serve to meet energy deficit to cottage industries in developing countries like Nigeria. In addition, our study shows that good waste management practice could be turned to an important wealth creation source. Good waste management, in global environmental sustainability concept, involves reducing waste, changing consumer habits or increasing the selectively collected and recyclable proportion of waste [47]. In our experiment to depict an example of good waste management procedure, we showed that gas production rate has a positive correlation with digester temperature, where the VS/TS ratio shows direct proportionality to the BMP of biogas substrates. Also, inoculum addition significantly affects the gas production. However, there is room for further studies on the influence of inoculum type, retention time and temperature on the rate and composition of gas production to help to know how the technology can be further improved upon. Biogas production is feasible and advantageous economically, environmentally and socially, and it can be used as an energy source in regions that are substrate rich but energy poor to supplement energy supply. The proposed business model stands to facilitate this by making use of existing resources efficiently.

Acknowledgements The authors would like to thank the Department of Chemical Engineering, OAU, and the Center for Energy Research and Development, CERD, OAU, for access to facilities during the duration of this project. Also, conduct of the research was encouraged through earlier support by funding from the Department for International Development (DfID) under the Climate Impact Research Capacity and Leadership Enhancement (CIRCLE) programme. The funders had no role in study design, data collection and analysis, decision to publish, or preparation of the manuscript.

\section{Compliance with ethical standards}

Conflict of interest On behalf of all authors, the corresponding author states that there is no conflict of interest.

Open Access This article is licensed under a Creative Commons Attribution 4.0 International License, which permits use, sharing, adaptation, distribution and reproduction in any medium or format, as long as you give appropriate credit to the original author(s) and the source, provide a link to the Creative Commons licence, and indicate if changes were made. The images or other third party material in this article are included in the article's Creative Commons licence, unless indicated otherwise in a credit line to the material. If material is not included in the article's Creative Commons licence and your intended use is not permitted by statutory regulation or exceeds the permitted use, you will need to obtain permission directly from the copyright 
holder. To view a copy of this licence, visit http://creativecommons .org/licenses/by/4.0/.

\section{References}

1. Turner DA, Williams ID, Kemp S (2015) Greenhouse gas emission factors for recycling of source-segregated waste materials. Resour Conserv Recycl 105:186-197

2. Ackerman $F(2000)$ Waste management and climate change. Local Environ 5(2):223-229

3. Sensoneo (2020) The biggest waste producers worldwide: Sensonseo Global Waste Index 2019. https://sensoneo.com/senso neo-global-waste-index-2019/ Accessed from 17 Jun 2020

4. Bhada-Tata P, Hoornweg DA (2012) Waste generation. In: Urban development series knowledge papers. World Bank group, pp. 8-12

5. Ogwueleka TC (2009) Municipal solid waste characteristics and management in Nigeria. Iran J Environ Health Sci Eng 6(3):173-180

6. Sridhar MKC, Hammed TB (2014) Turning waste to wealth in Nigeria: an overview. J Hum Ecol 46(2):195-203

7. Awosusi AO (2010) Assessment of environmental problems and methods of waste management in Ado-Ekiti, Nigeria. Afr Res Rev 4(3b):331-343

8. Oladepo OW, Ilori MO, Taiwo KA (2014) Assessment of the waste generation and management practices in Nigerian food industry: towards a policy for sustainable approaches. Am J Sci Ind Res 6(1):12-22

9. Chand M, Upadhyay BP, Maskey R (2012) Biogas: option for mitigating and adaptation of climate change. Lap Lambert Academic Publ, Germany

10. Chand M, Upadhyay B, Maskey R (2011) biogas option for mitigating and adaptation of climate change. Ren Sym Comp. 1.

11. Bacenettia J, Ducab D, Negria M, Fusic A, Fialaa M (2015) Mitigation strategies in the agro-food sector: the anaerobic digestion of tomato purée by-products. An Italian case study. Sci Total Environ 526(1):88-97

12. Clemens $H$, Bailis R, Nyambane A, Ndungu V (2018) Africa biogas partnership program a review of clean cooking implementation through market development in East Africa. Energy Sustain Dev 46:23-31

13. Hoo PY, Hashim H, Ho WS (2018) Opportunities and challenges: landfill gas to biomethane injection into natural gas distribution grid through pipeline. J Clean Prod 175:409-419. https://doi. org/10.1016/j.jclepro.2017.11.193

14. Cioabla AE, lonel I, Dumitrel GA, Popescu F (2012) Comparative study on factors affecting anaerobic digestion of agricultural vegetal residues. Biotechnol Biofuels 5(1):39

15. Bond T, Templeton MR (2011) History and future of domestic biogas plants in the developing world. Energy Sustain Dev 15:347-356

16. Mungwe JN, Colombo E, Adani F, Schievano A (2016) The fixed dome digester: an appropriate design for the context of subSahara Africa? Biomass Bioenergy 95:35-44

17. Mutungwazi A, Mukumba P, Makaka G (2018) Biogas digester types installed in South Africa: a review. Renew Sustain Energy Rev 81:172-180

18. Oliveira F, Doelle K (2015) Anaerobic digestion of food waste to produce biogas: a comparison of bioreactors to increase methane content a review. J Food Process Technol 6(478):2

19. Zhang R, El-Mashad HM, Hartman K, Wang F, Liu G, Choate C, Gamble $P$ (2007) Characterization of food waste as feedstock for anaerobic digestion. Bioresour Technol 98:929-935
20. Brown D, Li Y (2013) Solid state anaerobic co-digestion of yard waste and food waste for biogas production. Bioresour Technol 127:275-280

21. Li Y, Park SY, Zhu J (2011) Solid-state anaerobic digestion for methane production from organic waste. Renew Sustain Energy Rev 15:821-826

22. Wang X, Lu X, Li F, Yang G (2014) Effects of temperature and carbon-nitrogen $(\mathrm{C} / \mathrm{N})$ ratio on the performance of anaerobic co-digestion of dairy manure, chicken manure and rice straw: focusing on ammonia inhibition. Plos One 9(5):e97265

23. Dioha IJ et al (2013) Effect of carbon to nitrogen ratio on biogas production. Int Res J Nat Sci 1(3):1-10

24. Seadi TA et al (2008) Biogas handbook. University of Southern, Esbjerg

25. Raja IA, Wazir S (2017) Biogas production: the fundamental processes. COMSATS Institute of Information Technology, Pakistan

26. Rajput A, Sheikh Z (2019) Effect of inoculum type and organic loading on biogas production of sunflower meal and wheat straw. Sustain Environ Res. https://doi.org/10.1186/s4283 4-019-0003-x

27. Esposito $\mathrm{G}$ et al (2012) Bio-methane potential tests to measure the biogas production from the digestion and co-digestion of complex organic substrates. Open Environ Eng J 5:1-8

28. Motte J-C et al (2013) Total solids content: a key parameter of metabolic pathways in dry anaerobic digestion. Biotechnol Biofuels 6(1):164

29. Pratima KC, Bakta BA (2015) Production of biogas from slaughterhouse waste in Lalitpur sub-metropolitan city. s.l., s.n., pp. 143-149.

30. Jekayinfa SO, Olajide JO (2007) Analysis of energy usage in the production of three selected cassava-based foods in Nigeria. J Food Eng 82(2):217-226

31. Oladejo D, Okunzuwa M, Adedeji KA, Oluoti KO (2016) Determination of energy profile in processing cassava (Manihot Species) into 'gari'in a local oven. J Sci Res Rep 11(2):1-8

32. FAO (1998) Storage and processing of roots and tubers in the tropics, a publication of food and agriculture organization of the United Nations agro-industries and post-harvest management service, agricultural support systems division. http://www.fao. org/3/x5415e/x5415e0r.gif. Accessed from 26 Jun 2020

33. Geissdoerfer M, Savaget P, Evans S (2017) The Cambridge business model innovation process. Camb Bus Model Innov Process 8:262-269

34. Osterwalder A, Pigneur Y (2010) Business model generation: a handbook for visionaries, game changers, and challengers. John Wiley, Hoboken

35. Carrasc I (2017) 9 business models. https://ehorus.com/businessmodels/ Accessed from Apr 2019

36. Bergasse $E$ (2015) Rural electrification and the different business Models. Bridgetown, s.n

37. Bhasin H (2019). 23 Types of Business Models. https://www.marke ting91.com/23-types-of-business-models/ Accessed from Apr 2019

38. Das S (2019) What is a business model? Types of business models. https://www.feedough.com/what-is-a-business-model/ Accessed from Apr 2019

39. Planet Natural (2020) Carbon-to-Nitrogen Ratios. Available online at https://www.planetnatural.com/composting-101/ making/c-n-ratio/. Accessed 8 Dec 2020

40. Bekiaris G, Triolo J, Peltre C, Pedersen L, Lars SJ, Sander B et al (2015) Rapid estimation of the biochemical methane potential of plant biomasses using Fourier transform mid-infrared photoacoustic spectroscopy. Bioresour Technol 197:475-481

41. Lesteur M et al (2011) First step towards a fast analytical method for the determination of biochemical methane potential of 
solid wastes by near infrared spectroscopy. Bioresour Technol 102:2280-2288

42. Research Australia (2017) Research Australia. https://www.resea rchaustralia.com.au/the-subscription-revenue-model-vs-pay-asyou-go/ Accessed from Apr 2019

43. Zhou H, Wen Z (2019) Solid-state anaerobic digestion for waste management and biogas production. Adv Biochem Eng Biotechnol 169:147-168. https://doi.org/10.1007/10_2019_86

44. Veeken AHM, Hamelers BVM (2000) Effect of substrate-seed mixing and leachate recirculation on solid state digestion of biowaste. Water Sci Technol 41(3):255-262

45. Brown D (2012) Comparison of solid-state to liquid phase anaerobic digestion of lignocellulosic biomass for biogas production. Bioresour Technol. https://doi.org/10.1016/j.biort ech.2012.08.051
46. Jaramillo P, Matthews HS (2005) Landfill-gas-to-energy projects: analysis of net private and social benefits. Environ Sci Technol 39(19):7365-7373

47. Mezei C, Kovács SZ, Trenyik T, Nagy I (2018) Energy potential of waste: case study of the Hungarian waste management system. In: 16 . Skup o prirodnom plinu, toplini i vodi $=16$ th natural gas, heat and water conference: 9. Međunarodni skup o prirodnom plinu, toplini i vodi $=9$ th International natural gas, heat and water conference. Osijek, Horvátország, 2018.09. 26-2018.09. 28. (pp. 189-198). JJ strossmayer university of osijek mechanical engineering faculty in slavonski brod

Publisher's Note Springer Nature remains neutral with regard to jurisdictional claims in published maps and institutional affiliations. 